\title{
A strategy for obtaining social benefits from the gene revolution
}

L.A.B. de Castro

Correspondence

L.A.B. de Castro

UniCeub, SEPN 707/907

Reitoria

70790-075 Brasília, DF

Brasil

E-mail: luiz.castro@uniceub.br

Received April 13, 2004 Accepted July 30, 2004
Centro Universitário de Brasília, UniCeub, Brasília, DF, Brasil

\begin{abstract}
The strategy described in the present paper offers details about the possibility for Brazil to play a more substantial role in the gene revolution. If successfully applied, the powerful science-based technology currently available in Brazil can contribute to extend the benefits of the gene revolution to the poorest countries, very much like the Green Revolution did in the past, thereby reducing the hunger syndrome which claimed the lives of millions of people in some Asian countries, particularly Pakistan and India, decades ago. In his visit to Brazil in February 2004, Norman Borlaug had the opportunity to witness the success of Brazilian agriculture. At a Conference held at ESALQ - Superior School of Agriculture Luiz de Queiroz in Piracicaba, SP, Brazil, he stated that the 21st century revolution will come from Brazil in the area of agriculture. He also said that reducing hunger is essential for the world to achieve socioeconomic stability. A central question remains unanswered: who will fund this revolution? The FAO 2003-2004 Annual Report listed the barriers preventing the gene revolution from reaching the poorest countries: inadequate regulatory procedures - Intellectual Property Rights and Biosafety, poorly functioning seed delivering systems and weak domestic plant breeding capacity; all are discussed in this paper.
\end{abstract}

\section{Extending the benefits of the gene revolution to the poorest countries - the challenges ahead}

An important Congress held in Bologna in May 2003 (1) included in the agenda a major question about the gene revolution: is it possible to extend its benefits to poor developing countries? Some of the speakers representing the expectations of developing countries at the Congress stated that these benefits have not reached the very poor countries in a significant manner, and that the advances of biotechnology seem to be inaccessible to them. It has been recognized for
Key words

- Gene revolution

- Large scale monitoring of genetically modified plants

- Intellectual Property Rights (IPR)

- Patent and plant breeding laws

- Foundation seed programs ..................... many years that the gene revolution has made relevant advances in the area of agricultural crops (2). It is a fact, however, that the genetically modified (GM) plant products currently available are not the answer to the major biological and environmental restrictions which prevent the growth of agriculture in many tropical countries, particularly in semiarid regions. The limitations of plant productivity by environmental stress factors were recognized more than twenty years ago (3). This problem was not contemplated by the Green Revolution and continues to be a major challenge for the expansion of the world's grain production required by demo- 
graphic pressure (4), which will need to use infertile and physically very poor soils.

Mechanisms to strengthen the collaboration between the public and private sectors in international agricultural research in biotechnology have been discussed since the eighties (5). Efforts to enhance biotechnology research in Africa go back to the early nineties (6). Literally billions of dollars have been spent during the last two decades by both the public and private sectors. However, the adoption of agricultural biotechnology by African countries continues to be a very controversial and complex topic. AntiGM campaigns - now supported by the Cartagena Protocol which came into force in September 2003 (http://www.biodiv.org) have succeeded in blocking GM imports to hungry populations in Africa (7). Arguments in favor of or against the adoption of GM technology in Africa continue to increase while crop production on the continent has dropped by $8 \%$ from 1980 to 1995 , requiring African countries to import rice to feed starving populations that consistently grow every year. In three decades, rice imports have increased over 12-fold, to about 3.2 million ton/year, at a staggering cost of about US $\$ 1$ billion, and the demand for more rice is growing by $5 \%$ every year (8).

According to the report by the UN Millennium Hunger Task Force published last year (9), the perspective is that 183 million people in Africa will be undernourished by 2030. Jean Ziegler, Human Right for Nutrition Special UN Representative, declared in her Third Annual Report presented before the United Nations that one child younger than 10 years dies every $7 \mathrm{~s}$ directly or indirectly due to hunger. These numbers agree with another official report by FAO (10) stating that 6 million children under the age of 5 years die each year in the developing world as a result of hunger, included amongst the 11 million children that die every year due to infectious diseases. UNICEF indicated that more than 1 billion children suffer the effects of hunger (11). Jean Ziegler's report states that hunger kills 100,000 people every day and that the number of people with food nutrition deficiencies amounted to 840 million in 2002 and is increasing. The conclusion of the report is that the goal of international community to reduce by half child mortality and the number of people suffering from hunger by 2015 will not be achieved.

It is not surprising then that public opinion is clamoring for a solution for these problems with the expectation that the world's poorest regions in Central and West Africa could gain the most from the advances of biology (12,13). In May 2004, one year after the Bologna Congress previously cited (1), the FAO (14) stated: "The gene revolution: great potential for the poor, but no panacea. Only a few countries are benefiting so far - food crops of the poor need more attention". The FAO 2003-2004 Annual Report (14) recognizes that $70 \%$ of the world's poor still live in rural areas and depend on agriculture for their survival. Thus, agricultural research can lift people out of poverty by boosting agricultural incomes and reducing food prices. More importantly, though, agricultural biotechnology can increase the values of the crops for the poor by making crops work as factories for the production of high value molecules for different applications, particularly pharmaceuticals (15).

\section{Regulatory issues have inhibited the access of developing countries to the products of the gene revolution}

When the first GM plant was commercially released in 1995, worldwide campaigns led by non-governmental organizations were launched against it. In Brazil they succeeded in every legal battle against GM plants since 1997, not for scientific but for political and ideological reasons. Farmers were legally denied this technology in Brazil from September 1998 to September 2003. During this 
period, however, the illegal cultivation of glyphosate-resistant soybean spread, and estimates based on the increase in the soybean cultivated area compared to the reduced demand for non-GM soy seed indicate that the herbicide-resistant GM soybean may occupy $1 / 3$ of the soy area planted commercially in Brazil today. The legal battles are not over and the Biosafety Legislation has been under review by the Brazilian Congress for more than 2 years. Unfortunately, this problem is not limited to Brazil. Mexico has the same problems $(16,17)$ and in Europe plant genetic engineering has retraced its steps compared to its performance during the eighties for political reasons and lack a correct public perception. The Max Planck Institute, a pioneering institution in the area of plant genetic engineering when this technology started during the eighties, performed only fifty field tests with GM plants during the year 2001 (18,19). In England, 154 field tests with GM plants were performed in 2000/2001 and this number dropped to 42 in 2003/2004.

Biosafety and intellectual property rights are issues often debated regarding genetically modified crops (20). In Africa this task is presumably being facilitated by the African Agricultural Technology Foundation (AATF). The Rockefeller Foundation has supported Intellectual Property Rights (IPR) and Biosafety issues in Africa (2). However, problems related to IPR and Biosafety have delayed the commercial release of Golden Rice $(12,13)$. In fact, the commercial use of almost all crops produced by biotechnology depends on lengthy intellectual property rights negotiations, and in addition requires a compatible interpretation of the laws of Patent and Plant Breeders Rights (21). In the case of Golden Rice, many companies claimed patents on the technologies used to create this nutritious crop. In addition, biosafety requirements have extended the process of placing Golden Rice on the market for over 4 years (22), despite the harm- less nature of the traits involved. There is no need to emphasize the importance of this GM rice, which has the potential to save millions of children in the developing world from the deadly effects of vitamin A deficiency (2). According to the previously mentioned report by Jean Ziegler, vitamin A deficiency kills one person every $4 \mathrm{~min}$. These tragic statistics cannot be ignored. Solutions cannot be postponed. It is imperative and urgent to set up a global effort to achieve a less hungry world capable of building capacities and jobs and focusing on major constraints for agriculture development in the tropics that can be solved by modern bioscience. Certainly many issues need to be reevaluated in view of regulations and public perception. Political and economic confrontations unfortunately may be at the bottom of this continuous war that must end in order to promote agricultural biotechnology worldwide. We will try to demonstrate that the most powerful instrument for its adoption by the poorest developing countries will be based on science, despite some positions contrary to this assertion (23). Elements for a strategy to fulfill this goal have been presented earlier (24) and additional considerations to complement this strategy will be presented in the present article, particularly with respect to some of the regulatory issues mentioned above.

\section{The need for and the strategy to perform large-scale ecological monitoring of genetically modified plants}

Previous risk assessment is the basis for the commercial release of GM plants in the United States (25) and in many other countries. Biosafety monitoring of GM plants beyond the experimentation scale, sometimes referred to as Tracking and Surveillance, is needed, but several pitfalls associated with large-scale monitoring have been identified in the literature, particularly those of a meth- 
odological nature (see Traynor et al., Chapter 5: Monitoring, Ref. 25). Post-commercial ecological monitoring of GM plants was discussed at a Workshop organized by the United States National Academy of Sciences in 2000 (26), but modest initiatives towards adopting large-scale long-term monitoring of GM plants followed. Large-scale or farmscale experiments conducted before the commercial release of GM plants practiced in some European countries are inadequate as a model for tropical developing countries, geographically sub-continental in size. This methodology would require a large number of experimental sites to cover all agricultural areas. In addition, these experiments should be repeated many years in a row due to the complexity of tropical ecology involving diverse ecosystems. Costs are unaffordable and shortcuts are not acceptable. As an example, the results of a three-year experiment performed in the UK led to conclusions that grossly underestimated the complexity of ecology (27) such as: "killing weeds inflicts collateral damage to the environment, because wild life depends on weeds, some native insects feed on them, butterflies sip their nectar, and birds eat their seeds". This poetic conclusion ignores the fact that the same weed species are of course massively available outside the area devoted to agriculture. Agriculture utilizes a very small percent of the area of the world, and this area is declining due to urbanization of late developing countries such as China (28). The most astonishing remark in the paper previously mentioned (27) was that: "populations of skylark, corn bunting and other common birds of the British countryside have declined over the past 30 years". This of course cannot be associated with GM plants, never released in England and never commercially released worldwide before 1995. On the other hand, chemicals have been sprayed all over the UK and in fact all over the world for the last fifty years. It is well documented that millions of tons of chemical chlorine-related insecticides were sprayed during the last five decades all over the world to reduce the loss of grains to insects, without success. We now spend globally near US\$8 billion per year in insecticides, have hundreds of insect pests resistant to chemicals, in addition to the hundreds of deaths caused by agrochemical intoxication every year in Brazil alone (29).

Short-term experiments cannot be accepted to predict significant long-term detrimental effects by GM plants on non-target populations of weeds and particularly of insects, because the patterns of population fluctuation in nature are complex. In the case of insects, these patterns were shown to be under the influence of many parameters and as such can only be understood after long periods of time, some times decades, of observation (30-32). Unless enough observation time is provided, it is unlikely that farmscale experiments will be able to answer this central question related to gene flow and its potential detrimental effect on non-target populations.

To further complicate the problem, a comprehensive report from the US National Academy of Science (33) released recently proposes to develop methods for the biological confinement of GM plants to prevent gene flow. One of these genetic-related confinement methods cited as variety genetic use restriction technology has the negative consequence to reopen a difficult discussion due to its association with the "Terminator" technology, designed to prevent gene flow, completely abandoned due to public campaigns against it from all sides. The report cites no hazardous consequences of gene flow from GM plants to wild species but mentions two examples, beets and rye, which became invasive as a consequence of genes flowing from cultivated (non-transgenic) varieties to related wild species, to justify the need for confinement methods.

One of the mistaken conclusions derived from the report cited (33) was to extend its 
findings to plants (34) under the argument that there is no possible efficient way to prevent genes from flowing, thus explaining the long time needed to develop new methods to fulfill this goal before the commercial release of these putative GM plants (35). The mistaken assumption behind this conclusion is that when genes flow from a GM to a wild species this event shall cause drastic environmental hazards.

When biosafety regulations were established and started to be implemented almost 20 years ago, it was never assumed that genes would not flow from GM plants as they do normally at a higher or lower rate depending on the species. The biosafety strategy for the commercial release of GM plants establishes a stepwise exercise of previous risk assessment and risk management. Since it is disputed whether small-scale experiments are sufficient to predict how GM plants will behave in large-scale commercial fields, risk management strategies must be developed and adopted. The fact, however, is that GM plants have been environmentally released continuously for almost twenty years and that there are close to 70 million hectares planted with GM cultivars this year worldwide and the numbers tend to increase. The evidence available (36) from the current state of knowledge is that the potential impact on the environment of the transgenic crops released is likely to be negligible. The need for confinement was of course never mentioned in the American National Academy of Sciences report as an alternative for large-scale, long-term, ecological monitoring of GM plants (33) nor was the need to reverse the release of the GM plants widely used in the world.

From the previous analysis, the largescale ecological monitoring of existing GM plantings is probably indicated as the only solution to monitor the behavior of the GM plants that have been commercially released for over a decade now, for two reasons: 1) to prevent detrimental impacts on the environ- ment if these impacts are pointed out scientifically as likely to occur, and 2) to demonstrate the opposite, e.g., the positive environmental impacts of GM plantings as shown in the State of Rio Grande do Sul, Brazil, with the glyphosate-resistant GM soybean associated to no tillage. I visited the whole area illegally planted with this glyphosate-resistant soybean in close to 2 million hectares in the State of Rio Grande do Sul in 2003. Counties included Tupaceretã, Joia, Passo Fundo, Cruz Alta, among others. I personally saw the benefits of this technology associated to no tillage for seven years in a soybean area that had given up the weed control of soybean with post-emergence herbicides.

The National Academy of Sciences report recognizes that human error does and will always eventually occur and that the withdrawal of GM plants from the environment when human error occurred in a few cases had no effect on human health or on the environment itself (33). In fact, this was done in Brazil on a large-scale basis in the past with non-GM citrus plants due to viruses and with non-GM coffee due to rust, and we are doing it again with non-GM cocoa and banana due to "witches' broom" and black sigatoka, respectively, all pathogenic fungi.

However, based on available scientific data, it should be assumed that the flow of an inserted gene from a GM plant to a wild species does not constitute an irreversible ecological catastrophe. GM plants are not intrinsically dangerous. Recombinant DNA technology was developed thirty years ago. Hundreds of GM plant events were properly handled according to biosafety strategies and the case studies of released GM plants that caused concern resulted from human errors rather than from the unpredicted potential danger of the GM plant itself and were corrected with no effects on human health or on the environment itself (33).

Starting in 1983, we have been conduct- 
ing large-scale monitoring of a non-GM baculovirus using bioassays and molecular analysis after its commercial release in Brazil. The virus is used for the biological control of Anticarsia gemmatalis, an insect pest infesting soybean, and is currently applied to 1.5 million hectares of soybean/year. This is the largest biological control experiment in the world, and after twenty years we have no evidence that the virus will become a plant pest as many anticipated.

In Brazil, the need for large-scale monitoring of GM plants has been recognized since 1998 as a precondition for the commercial release of the first GM crop: the RR soybean. The National Biosafety Committee of Brazil determined and later approved the large-scale ecological monitoring of this GM plant for five years in seven states representing the soybean agricultural area in the country and selected the parameters to be investigated, i.e., soil analysis: physical and chemical properties, and biological analysis: nematodes, fungi, microorganisms, gene flow, invasiveness/weed resistance to the herbicide, and plant and soil herbicide residues (37).

As stated earlier, five years may be too short a period to predict the potential damage or benefit of any GM plant event to the environment, but this proposal (never implemented for legal reasons) for the post-commercial large-scale monitoring of a GM plant event was the first of its kind anywhere in the world. Large-scale ecological monitoring by sampling has been exercised for decades by institutions such as the Oak Ridge National Laboratory (38), and by the USDA - The Natural Resources Inventory (39). Conceivably, methodologies can be developed to perform ecological monitoring of GM plants by sampling specified parameters, using the experience of these institutions as reference. This methodology, unfortunately not yet applied to GM plantings, will provide an answer to all the speculative questions related to the potential damage of GM plants that may result from the gene expression or flow from a GM to non-target populations.

\section{The patent legal rights systems applied to biotechnology and the plant breeder's intellectual property rights - are they compatible?}

We mentioned that large private companies have announced their willingness to share technology free of charge with African scientists who are working with small farmers in sub-Saharan Africa. This willingness does not imply that the IPR issues are resolved. To make the advances in biotechnology available to breeders, it is necessary to assure a fair coexistence between plant breeder's and patent rights regimes or laws, making them compatible. The boundaries between plant breeder's and patent rights applied to biotechnology must be established to facilitate the adoption of agricultural biotechnology worldwide, particularly in developing countries where gene discovery is lagging behind and most genes are legally protected by patents (21). This issue has been under discussion by both the World Intellectual Property Organization (WIPO) and Union Internationale pour la Protection des Obtentions Végétales (UPOV) for at least two decades $(40,41)$. Unfortunately, most attempts to determine the frontiers between the laws were coordinated by lawyers with no in-depth knowledge of biology that would permit them to find adequate solutions. This occurred recently when WIPO instituted a Working Group on Biotechnology (42), an effort that turned out to be inconclusive.

The first step to make the two sets of laws compatible should take into consideration the definition by UPOV of an essentially derived plant cultivar in its last version (43). When applied to GM plants, an essentially derived plant cultivar, as the name implies, differs from a commercially derived plant cultivar mainly by a transgene transferred to its genome. This is easily accomplished by 
crossing a GM plant event with a commercial plant cultivar of interest and successively backcrossing further to recover all the commercial characteristics for the plant cultivar to be released, with the GM trait being added to its genome as intended.

This link between molecular biology, molecular genetics and breeding, possible through essentially derived plant cultivars, is the fastest and easiest way to combine transgenes from a genetically engineered plant event, often offered by gene companies, with the best genotypes from plant breeding programs available and adapted to developing country conditions. This method reduces the probability of unintended release of engineered genes into the environment since the introgression of the genes can be performed under confined conditions. Lengthy genotype/environment field testing is often not required since the resulting essentially derived plant cultivar, as the name indicates, are genetically similar to the commercial cultivars previously selected for the introgression of the engineered gene. The method is also easily adaptable to crops such as rice and beans, important components of the diet of poor populations and small farmers in Brazil and Africa. In addition, in tropical countries where the winter is not severe two and sometimes three generations can be produced in one year depending on the species considered.

Now the question to be answered is simple: What should be the legal rights of the plant breeder governed by the UPOV system and what should be the rights of the gene company, or, as often called, the life science company that patented the transgene under a patent law?

A plant breeder should be free to use a plant variety which includes in its genome a patented transgene related to a patented gene process, if the final product of the breeding process is not related to the patented gene process. This means that the breeder used the plant variety or cultivar not to obtain any product related to the patented gene or patented process, and thus used the cultivar for other reasons, even if the cultivar had the transgene in its genome. Since the patented gene was not directly or indirectly used in the breeding process because the plant product, as stated above, was not intended to be related to the patented transgene or gene process, obviously, regarding the product obtained, the breeder cannot claim the advantages inherent to the products derived from the patented transgene or its related patented process. This is fair for the breeder because the owner of the patented gene does not have the rights to block the use by a plant breeder of entire genomes expressing genes for thousands of other traits unrelated to the patented gene or process. Gene companies cannot legally claim the ownership under a patent law of entire genomes which they have not intellectually "invented".

However, the use by a breeder of any plant/variety protected or not, expressing a patented gene responsible for a patented gene process, to obtain by any method a new variety to be intellectually protected or not, but claiming or taking full advantages of the patented transgene or related process for that trait, as in the process of obtaining an essentially derived plant cultivars, should not be allowed without the consent of the patent holder. This applies even if the breeder does not make direct use of the patented gene as a marker or probe during the breeding process (21), which in fact may not be necessary. On the basis of this principle, farmers in the State of Rio Grande do Sul, Brazil, have recognized the legal patent rights of Monsanto for the RR technology and are paying a technology fee to the gene company.

The other side of the coin is that gene companies cannot equally make use of protected plant varieties without consent of the breeder even if the product is an essentially derived plant cultivars. Normally gene companies do not have the experience needed for plant breeding, particularly in the tropics, 
and tend to utilize essentially derived plant cultivars for the reasons already mentioned, as we proposed previously (24). The legal limits described may not resolve all possible problems between breeding companies and gene companies but establish an avenue to be followed by both sides because it facilitates the enforcement of the rights when varieties are registered by the breeders or by the gene companies. The products of this gene revolution are the functionally characterized genes but the farmers do not plant genes, they plant seeds of protected varieties. The important characteristic of a law is not only to be fair, but to be enforceable. Our suggestion to gene companies, particularly when dealing with developing countries, is that the laws in these countries, when they exist, do not oblige farmers to buy seed every year. In fact, they assure the rights of the farmer to save his own seed. Agreements must then be negotiated between gene companies and breeding companies. Seed companies (when they are not the breeding or the gene company) will add their final fees to the price of the seed and the farmer will decide on the basis of the aggregate value of the technology built in the seed.

\section{Basis for a strategy to extend the benefits of the gene revolution to resource-poor developing countries}

In a continuous struggle to reduce hunger and poverty, Brazil has surveyed geographically the incidence of both parameters recently. On the basis of per capita income, 57.7 billion, or $35 \%$ of the Brazilian population, ranked below the poverty level. There are 21.7 million, or $12.9 \%$ of the population, living at extreme poverty levels. More than half $(52.8 \%)$ of this population resides in the Northeast region of the country. Considering the 100 poorest counties, in Brazil 78\% are also located in the Northeast. In some rural areas of the Northeast the poverty average is twice the national average (44). We have gradually succeeded in reducing child mortality by prevention during the last decades, but funds to be applied to social programs to reduce hunger have increased. Just as an example, the cost of the Zero Hunger Program in Brazil will be close to US\$2 billion/year just to assure two meals/day for each of the 44 million poor people. The Zero Hunger Program plans to benefit twice as many people as the population ranked at the extreme poverty level identified by the program at a cost of US\$17/month, and will not be able to increase its coverage every year unless we can reduce poverty with strategies that build up incomes as proposed here through agriculture.

The Brazilian socioeconomic problem is small compared to the world's poorest regions of West and Central Africa, where 240 million, one third of the African population, struggle for food on less than US $\$ 1 /$ day (45), and thousand die of hunger every day. Rice imports to feed African populations in these regions amount to US $\$ 1$ billion/year and are growing at the rate of 5\%/year, in agreement with our experience in Brazil.

In order to reduce the gradual and consistent increase of hunger and the cost of social programs it is imperative to apply, in parallel to social programs, long-term strategies to build human survival capacity through jobs. We have learned that agriculture is the most suitable instrument to fulfill these goals, and last year the Semi-Arid National Institute (INSA) was created in Brazil to develop and apply available agricultural technologies, including the advances of the gene revolution, to reduce hunger in this region. As part of the agenda of INSA, we are operating the Northeast Biotechnology Network Program (RENORBIO). Under this program, selected science and technology projects are being funded. We are confident that these instruments now available can facilitate the extension of the results obtained in Brazil to the agriculture of the world's poorest populations of Africa. The Northeast of Brazil 
and West/Central Africa have similar agricultural problems.

It should not be overlooked, though, that the ability of developing countries to benefit from the gene revolution requires the organization of the agricultural sector. Brazil tripled its grains production during the last four decades but this was a long-term effort. First, geneticists learned gradually how to breed plants for the tropics and then a law to regulate the commercialization of seeds was enacted forty years ago. Finally, foundation seed programs allowed the consolidation of a seed industry to transfer the work of the geneticists to farmers. In anticipation of the gene revolution, since the seventies, consistent investments in the training of human resources were made in Brazil in the areas of plant cell, molecular and developmental biology and genome analysis to offer the advances of biology to plant breeders. A strategy to transmit the advances of biological science to other developing countries, particularly to some of the poorest African countries, calls for strengthening the cooperation between the best plant geneticists from these countries to team up with the best plant geneticists in Brazil in order to produce adapted cultivars of a few grains and staple crops for the semiarid regions. To base this strategy on a single staple crop as proposed recently (46) would be too risky. The world had to replace all corn hybrids because an inbred line common to all of them was susceptible to a fungus. This cooperation is essential to properly design the additional activities to be implemented in the agricultural sector, and will add to the capacity building of academics in Africa, a goal to be achieved by gradually making available the most advanced biological tools being used in Brazil, e.g., functionally characterized genes needed to produce the plant cultivars mentioned above. The best plant genetics for semiarid regions, incorporated into foundation seed programs, will yield certified seeds. The strategy as a whole will require estab- lishing partnerships between ongoing activities in Africa (WARDA - The African Rice Center and Syngenta Foundation for Sustainable Agriculture) and the EMBRAPA Research Centers located throughout several Brazilian States. This paper is a general, summarized description of the strategy and derived basic outputs needed for modern science to have an impact on the agriculture of the poorest countries as a long-term effort aimed at reducing hunger and child mortality, as described below.

\section{Goals, institutional basis and funds for the strategy}

We mentioned that the initiative described can be facilitated by the INSA established in Brazil last year in order to apply the advances of the gene revolution to reduce hunger in this region. No new laboratories will be built. INSA will have an office in the Northeast State of Paraíba and work virtually through networks. It was also mentioned that we are operating in the agenda of INSA, The Northeast Biotechnology Network Program - RENORBIO. This science and technology Program created in 2003 was adopted within the portfolio of programs of the Ministry of Science and Technology - MCT in Brazil. The Ministry of Science and Technology has initially assigned funds (US $\$ 3$ million) from the INSA budget, and has also applied limited financial resources from the National Biotechnology Fund to support RENORBIO (http://www.bnb.gov.br/etene/ fundeci). These funds will be available in 2004 for projects focusing on plants resistant to drought, pests and soil aluminum toxicity, which affect more than half of tropical soils. Additional funds will come from an instrument included in the National Biosafety Legislation (under review in Congress), which established a fund for biotechnology projects intended for products of public interest. The projects will be funded by a fraction of US\$1.00/hectare planted with GM 
crops in the country. It is conceivable that this principle could be negotiated internationally. These financial resources will support and strengthen several ongoing activities in Brazil which have goals related to those mentioned above. Genes available in Brazil were expressed in plant genotypes adapted to tropical agricultural conditions and are ready to be backcrossed into genomes adapted to the semiarid regions. In fact, some plant cultivars such as dry beans resistant to Golden mosaic virus and potato cultivars resistant to viruses are ready to be released as proofs of concept, pending biosafety analysis, field testing and, eventually, IPR negotiations. Other functionally characterized genes will result from the support to projects concerning the rice genome, nematodes and insect resistance and nitrogen fixation by grasses also in progress in Brazil. The development of grasses capable of fixing $\mathrm{N}_{2}$ from the air (47) is the most important agricultural project supporting the growing demand for food that will result from the demographic pressure on agriculture production (48). The availability of oilderived urea, which pollutes the soil and the water, will severely restrict grain production worldwide in the decades to come (49).

All the projects mentioned involve a number of institutions in Brazil and abroad but are mainly the responsibility of the National Center of Genetic Resources and Biotechnology - CENARGEN, the EMBRAPA Soybean Center in Londrina, State of Paraná, EMBRAPA Corn and Sorghum Center in Sete Lagoas, State of Minas Gerais, EMBRAPA Rice and Beans Center in Goiânia, State of Goiás, EMBRAPA Vegetable Crops in Brasília, the Agro-Biology Research Center of EMBRAPA in the State of Rio de Janeiro, and the Biochemistry Department of the Federal University of Rio de Janeiro. Functional characterization of genes must elucidate important mechanisms to neutralize pathogen activity in plants for disease and pest resistance and to avoid environ- mental stress. Advantage will be taken of the scientific developments obtained with arabidopsis (50), tobacco (51), rice $(52,53)$, and C. elegans $(54,55)$, among others. Genes will also result, if possible, from cooperation with ongoing international projects waiting to be funded - USAID (Comparative Genetics, Isolation and Pyramiding of Genes for Aluminum Tolerance in Rice and Wheat; 56), and others being funded such as the CGIAR Challenge Program (57). Finally, genes could also come from the large private sector companies after the public announcement of their willingness to share their technology free of charge with African scientists who are working with small farmers in subSaharan Africa, precisely in the same areas as mentioned above. However, the most important strategy for developing countries in order to identify and characterize the genes needed for their breeding programs is to deal with biology in a convergent way to compensate for the reduced number of scientists working in molecular biology. Technically this is also recommended because the functional analysis of genomes shows the obvious possibility to use genes from organisms very distant phylogenetically to find their relatives in plants or animals performing the same functions. As an example, Kono's team in Japan (58) demonstrated that Igf2 is an essential gene for embryo growth and development and is only turned on in the sperm. Another gene, called H19, turns off the Igf2 gene in eggs. The scientists removed the "off switch" (H19), allowing the Igf2 gene to turn on, and produced parthenogenesis in mice. The counterpart of parthenogenesis in plants is apomixis, a natural phenomenon particularly in grasses and citrus plants. The molecular basis of this phenomenon in plants has not been fully elucidated but this goal could benefit from findings obtained with mice, such as the introduction of apomixis in plants when advantageous for breeding programs. Finally, it is absolutely necessary to build aggregate value into the crops of poor coun- 
tries. Several examples indicate that plants can become important protein expression systems for molecules of high intrinsic value such as pharmaceuticals. It is naive to expect, as stated in the FAO 2004 Annual Report, that the "orphan crops", i.e., cow- pea, millet and sorghum, will lift people out of poverty by boosting agricultural incomes. This will only happen if these crops express special protein molecules, as already demonstrated (15).

\section{References}

1. In the Wake of the Double Helix: From the Green Revolution to the Gene Revolution (2003). Bologna, Italy, May 27 to 31. Abstracts and Final Program <http://137.204.42.130/doublehelix/index.html>. Proceedings (in press)

2. Abelson HP \& Hines JP (1999). The plant revolution. Science, 285: 367-368.

3. Boyer SJ (1982). Plant productivity and environment. Science, 218 : 443-448.

4. The United Nations (2003). World Population Prospects: The 2002 Revision - Medium Scenario, 2003. Population Reference Bureau.

5. Cohen LJ (1989). Strengthening Collaboration in Biotechnology: International Agriculture Research and the Private Sector. Proceedings of a Conference held April 17-21, 1988 in Rosslin, VA, USA. Agency for International Development, Washington, DC, USA.

6. Thottappilly GL, Monti DR, Mohan R \& Moore AW (1992). Biotechnology: Enhancing Research on Tropical Crops in Africa. CTA/IITA co-publication. IITA Ibadan, Nigeria.

7. Masood E (2003). A continent divided. Nature, 426: 224-226 (News Feature).

8. WARDA and AGCOM International (1998). Bintu and Her New African Rice: A Genetic Bridge to Food Security and Biodiversity. Video, $28 \mathrm{~min}$

9. Sachs J (2003) The Millenium Hunger Task Force Report. Overseen by Jeffrey Sachs, Director of the Earth Institute of Columbia University, New York.

10. FAO (2003). Undernourishment around the world - Hunger and Mortality 1-12. <http://www.fao.org>

11. Gordon D \& Townsend P (2003). Child poverty in the developing world, UNICEF. <etrowbridge@unicef.org><sarahv@unicef.org.uk>.

12. The New York Times (2003). Genetically modified foods and the poor. New York Times, October 13.

13. Piore A (2003). What green revolution? Newsweek Magazine, September $8(1,425)$.

14. FAO (2004). The gene revolution: great potential for the poor, but no panacea. Only a few countries are benefiting so far - food crops of the poor need more attention. The State of Food and Agriculture. Annual Report 2003-2004. FAONEWSROOM.

15. Gomord V, Sourrouille C, Fitchette AC, Bardor M, Pagny S, Lerouge P \& Loïc FL (2004). Production and glycosylation of plant-made pharmaceuticals: the antibodies as a challenge. Plant Biotechnology Journal, 2: 83-100.

16. The U.S. Chamber of Commerce (2002). Latin America Agricultural Biotechnology Initiative. Latin American Agricultural Biotechnology Forum, Washington, DC, USA, December 16.

17. Goldberg RB (2001). The History's Harvest, Where Food Comes From? Tape produced by the American Society of Plant Biology.

18. Frank L (2000). Plant biotechnology. Italian scientists blast GMO restrictions. Science, 290: 2046.

19. Gaskell G, Bauer WM, Durant J \& Allun CN (1999). Worlds apart?
The reception of genetically modified foods in Europe and the US Science, 285: 384-387.

20. Kennedy D (2003). Agriculture and the developing world. Science, 302: 357 .

21. de Castro LAB (2002). Intellectual property strategy and licensing experience with the co-existence of patents and plant variety protection systems. Proceedings of the Symposium on the Co-Existence of Patents and Plant Breeders' Rights in the Promotion of Biotechnological Developments, Session III. Organized by the WIPO and the UPOV Geneva, October 25, 2002.

22. Potrykus I (2003). Communication at the Congress: In the Wake of the Double Helix: From the Green Revolution to the Gene Revolution. Bologna, Italy, May 27 to 31. Abstracts and Final Program <http://137.204.42.130/doublehelix/index.html>. Proceedings (in press).

23. Barinaga M (2000). Asilomar revisited: lessons for today? Science, 287: 1584-1585.

24. de Castro LAB (2002). A new strategy for the development of agricultural biotechnology in Brazil. American Society of Agronomy Annual Meetings, Indianapolis, IN, USA, November 12-14. ASA Symposium Proceedings (in press).

25. Traynor PL, Frederick RJ \& Koch M (2002). Biosafety and Risk Assessment in Agricultural Biotechnology. A Workshop for Technical Training the Agricultural Biotechnology Support Project. Institute of International Agriculture, Michigan State University, USA.

26. The National Research Council (2000). Workshop on Ecological Monitoring of Genetically Modified Crops, July 13-14, Commission on Life Sciences/Board on Biology/Board on Agriculture and Natural Resources.

27. Stokstadt E \& Vogel G (2003). Mixed message could prove costly for GM crops. Science, 302: 542-543.

28. Brown LR (1995). Who Will Feed China. Wake-Up Call for a Small Planet. The World Watch Environmental Alert Series. State of the World and Vital Signs Series. Worldwatch Institute, Washington DC.

29. SINITOX (2004). National Poisoning Information System. <sinitox@cict.fiocruz.br>.

30. Jones GC, Ostfeld SR, Richard PM, Schauber ME \& Wolff OJ (1998). Chain reactions linking acorns to gypsy moth outbreaks and lyme disease risk. Science, 279: 1023-1026.

31. Zimmer C (1999). Complex systems: life after chaos. Science, 284 : 83-86.

32. Bjornstad NO, Peltonen M, Liebhold MA \& Baltensweller W (2002). Waves of larch budmoth outbreaks in the European Alps. Science, 298: 1020-1023.

33. The National Research Council (2004). Biological Confinement of Genetically Engineered Organisms. Committee on the Biological Confinement of Genetically Engineered Organisms. The National Academy Press. <http://books.nap.edu>. 
34. Stokstad E (2004). Genetically modified organisms. Experts recommend a cautious approach. Science, 303: 449.

35. de Castro LAB (2004) Genes are Flowing. <www.sbbiotec.org.br>.

36. Dale PJ, Clarke B \& Fontes EMG (2002). Potential for the environmental impact of transgenic crops. Nature Biotechnology, 20: 567574.

37. Comissão Técnica Nacional de Biosegurança (CTNBio) (1998). Instrução Normativa No. 18, Comunicado 54. <www.ctnbio.gov.br>.

38. Bartell S (2000). Workshop on Ecological Monitoring of Genetically Modified Plants - Examples of Ecological Monitoring - Using Ecological Monitoring in Risk-Based Environmental Monitoring. The National Academy of Sciences, July 13-14, Washington DC.

39. Lee W (2000). Workshop on Ecological Monitoring of Genetically Modified Plants - The Logistics of Monitoring. The National Academy of Sciences, July 13-14, Washington DC.

40. World Intellectual Property Organization (WIPO) (1987). Industrial Property Protection of Biotechnological Inventions. Report of the Committee of Experts on Biotechnological Inventions. Revised by the International Bureau Third Session, Geneva, June 29 to July 3.

41. Union Pour La Protection Des Obtentions Végétales (UPOV) (1982). La Engenieria Genética y las Obtenciones Vegetales. Simposio XVI Sesión Ordinaria del Consejo de la UPOV, Geneva, October 13.

42. World Intellectual Property Organization (WIPO) (1999). Issues for the Proposed WIPO Work Program on Biotechnology. Working Group on Biotechnology, Geneva, November 8-9.

43. UPOV (1991). Convenio Internacional para la Protección de las Obtenctiones Vegetales. Texto Oficial. Revisto em 19 de março de 1991.

44. Rocha S \& Albuquerque CR (2003). Geografia da pobreza extrema e vulnerabilidade à fome. Seminário Especial Fome e Pobreza, Rio de Janeiro, RJ, Brazil, Setembro de 2003. Estudos e Pesquisas No. 54. Copyright 2003, INAE - Instituto Nacional de Altos Estudos. <http:// forumnacional.org.br>.

45. WARDA - The Africa Rice Center (2003). New Rice for Africa (NERICA) Offers Hope to Women Farmers and Millions More. <http://www.warda.org/warda1/index.htm>.

46. Varmus H, Klausner R, Zerhouni E, Acharya T, Daar AS \& Singer PA (2003). Policy forum - public health grand challenges in global health.
Science, 302: 398-399.

47. Vargas C, de Pádua VLM, de Matos Nogueira E, Vinagre F, Masuda HP, da Silva FR, Baldani Jl, Ferreira PCG \& Hemerly AS (2003). Signaling pathways mediating the association between sugarcane and endophytic diazotrophic bacteria: a genomic approach. Symbiosis, 35: 155-180.

48. UNESCO (2003). UNESCO Institute for Statistics. www.uis.unesco.org

49. Teweles WL (1982). The New Plant Genetics. Vol. 1. Chapter V: Recombinant DNA and the Transformation of Plants (Interim Report). L. Williams Teweles \& Co., Milwaukee, WI, USA.

50. Apse MP, Aharon GS, Snedden WA \& Blumwald E (1999). Salt tolerance conferred by over expression of a vacuolar $\mathrm{Na}^{+} / \mathrm{H}^{+}$antiport in arabidopsis. Science, 285: 1256-1258.

51. de la Fuente JM, Ramíres-Rodrigues V, Cabrera-Ponce JL \& Herrera Estrella L (1997). Aluminum tolerance in transgenic plants by alteration of citrate synthesis. Science, 276: 1566-1568.

52. Yu J, Hu S, Wang J et al. (2002). A draft sequence of the rice genome (Oryza sativa L. ssp. indica). Science, 296: 79-92.

53. Goff AS, Ricke D, Lan TH et al. (2002). A draft sequence of the rice genome (Oryza sativa L. ssp. japonica). Science, 296: 92-100.

54. Hodgkin J, Horovitz RH, Jasny BR \& Kimble J (1998). C. elegans: sequence to biology. Science, 282: 2011.

55. Anonymous (1998). Genome Sequence of the Nematode C. elegans: A Platform for Investigating Biology. The C. elegans Sequencing Consortium*. Science, 282: 2012-2018. *For a list of authors see <http://genome.wustl.edu/gsc/C_elegans/> <http:// www.sanger. ac.uk/Projects/C_elegans $>$.

56. Gustafson P (2003). Aluminum tolerance in small grain cereals. In the Wake of the Double Helix: From the Green Revolution to the Gene Revolution. Bologna, Italy, May 27-31. Abstracts and Final Program <http://137.204.42.130/doublehelix/index.html>. Proceedings (in press).

57. Consultive Group for International Agricultural Research Centers (CGIAR) (2003). CGIAR Challenge Program - Unlocking Genetic Diversity in Crops for the Resource Poor.

58. Kono T, Obata Y, Wu Q, Niwa K, Ono Y, Yamamoto Y, Park ES, Sun Seo J \& Ogawa $H$ (2004). Birth of parthenogenetic mice that can develop to adulthood. Nature, 428: 860-864. <http://www.nature.com>. 